\title{
Działalność ruchów kobiecych w sieci - cyfrowe oblicze polskiego feminizmu
}

\author{
DAGMARA KOSTRZEWSKA ${ }^{1}$ \\ ${ }^{1}$ Akademia Pedagogiki Specjalnej im. Marii Grzegorzewskiej, ul. Szczęśliwicka 40, 02-353 Warszawa. \\ ORCID: https://orcid.org/0000-0003-3139-0243, Email: dkD4@aps.edu.pl
}

STRESZCZENIE: Autorka tekstu porusza temat wirtualnej działalności ruchów kobiecych w Polsce. Posługując się metodą netografii ze szczególnym wykorzystaniem analizy sieci społecznych przygląda się cyfrowemu obliczu polskiego feminizmu, zwracając uwagę na towarzyszące temu pozytywne, jak i negatywne aspekty walki kobiet w przestrzeni online. Głównym celem artykułu było zbadanie języka, jakim posługują się współczesne feministki w wirtualnym świecie, czy jest to język miłości, czy też język nienawiści. $\mathrm{W}$ artykule przedstawiono działania organizacji kobiecych w sieci, podejmując próbę nakreślenia głównych idei widocznych w dyskursie tych ruchów. Autorka dzięki przeprowadzonym analizom przedstawia oddziaływanie i wyraźnie nakreślające się intencje ruchów kobiecych w sieci ze szczególnym uwzględnieniem zarówno pozytywnych, jak i wrogich interakcji w feministycznej przestrzeni online.

SŁOWA KLUCZOWE: ruch kobiecy, Internet, feminizm, cyberprzestrzeń, netnografia, analiza sieci społecznych

\section{WPROWADZENIE}

Feminizm to słowo, które wywodzi się z łacińskiego „femina”, co oznacza „kobieta”. Pojęcie to oznacza ideologie, doktryny oraz ruchy, które skupiają się wokół równości prawnej, społecznej oraz politycznej zarówno kobiet, jak i mężczyzn (za: Tokarczyk 2005: 519). „Definicja feminizmu obejmuje doktrynę równych praw dla kobiet (w prak- 
tyce: zorganizowany ruch kobiet), jak i ideologię społecznych przeobrażeń, których celem jest nie tylko społeczna równość, ale także powstanie świata, który byłby światem kobiet [...]” (Humm 1993: 60). Ewa Lewandowska dodaje, że feminizm to nie tylko sama walka płci, ale również pojedyncza, jednostkowa aktywność kobiet oraz globalna siła ruchu społecznego (za: Lewandowska 2003: 64).

Za historyczny początek działań ruchów kobiecych uważa się rok 1792, kiedy to ukazała się publikacja Mary Wollstonecraft pod tytułem „Wołanie o prawa kobiet”. Autorka w monografii nawiązywała do problemów edukacji dziewcząt, nierównego statusu kobiet, czy też prawa kobiet do pracy. „Kobietom wmawia się od wczesnego dzieciństwa i uczy na przykładzie ich matek, że dzięki niewielkiej wiedzy na temat ludzkich słabości - słusznie nazwanej sprytem - łagodności charakteru, pozornemu posłuszeństwu i skrupulatnej trosce o zachowanie dziecinnego rodzaju przyzwoitości, uzyskują one ochronę mężczyzny. Wmawia się im również, że byleby były piękne, nic innego im nie potrzeba przez przynajmniej dwadzieścia lat życia” (Wollstonecraft 2011: 57)

Publikacja Wollstonecraft zapoczątkowała działania kobiet na całym świecie, które walczyły o prawa wyborcze, prawa do antykoncepcji, o prawo do odmienności i równouprawnienie, nie tylko kobiet, a wszystkich ludzi.

Od początku rewolucji minęło prawie 50 lat, jednak działania ruchów kobiecych wciąż mocno oddziaływają na ówczesne zmiany polityczne na całym świecie. Mimo coraz większej powszechności zjawiska badania socjologiczne pokazują, że w Polsce feminizm nie jest aprobowany nawet wśród kobiet, które doświadczają nierówności płci (por. Odrowąż-Coates 2015).

Natomiast "powszechnie ma miejsce dystansowanie lub negowanie pozytywnej roli feministki, a przede wszystkim brak wiedzy na temat feminizmu znajdujący wyraz w stereotypowych przekonaniach" (Wajbert-Wąsiewicz 2017: 99).

W XXI wieku „W miarę jak setki milionów ludzi zaczyna wchodzić we wzajemne interakcje za pośrednictwem rozmaitych społeczności internetowych i związanych z nim cuberkultur, nasze światy społeczne nabierają coraz bardziej cyfrowego charakteru” (Kozinets 2012: 13). W związku ze zmianami i postępami, zwłaszcza technologicznymi, jakie przechodzi obecnie społeczeństwo również działania ruchów kobiecych dążąc do jak najlepszego i spersonalizowanego przekazu przeniosły się na wielowymiarową, dającą większe możliwości oddziaływań płaszczyznę- do Internetu.

\section{METODOLOGIA I TŁO BADAŃ}

Ze względu na coraz większą cyfryzację społeczeństwa oraz przeniesienie się działalności wielu grup społecznych na płaszczyznę online, w tym również interesującą badacza społeczność ruchów kobiecych badania zostały przeprowadzone we wcześniej wspomnianym środowisku internetowym.

Autorka artykułu zdecydowała się na przeprowadzanie badań metodą netnografii z wykorzystaniem analizy sieci społecznych. Metoda netnografii to metoda, która w badaniach posługuje się obserwacją uczestniczącą do pracy w wirtualnym terenie. Metoda ta z powodzeniem wykorzystuje formy komunikacji zapośredniczonej przez 
komputer, w celu zebrania danych i dotarcia do etnograficznego zrozumienia oraz przedstawienia wybranych zjawisk (Kozinets 2012: 93).

Zgodnie z definicją kanadyjskiego profesora Roberta V. Kozinets (2012: 100), „określamy czystą netnografię jako metodę badań prowadzonych wyłącznie z użyciem danych wygenerowanych na podstawie interakcji, które odbywają się w Internecie bądź za pośrednictwem innych form komunikacji zapośredniczonych przez technologię (CMC, ICT) - czy będą to wywiady internetowe, uczestnictwo online, obserwacja internetowa, czy pobieranie danych".

Należy również wspomnieć, iż netnografia jako metoda badawcza jest silnie związana z metodą badań etnograficznych („Metoda etnograficzna polega na gromadzeniu informacji o wytworach materialnych, stosunkach społecznych, przekonaniach i wartościach danej społeczności. W procesie zbierania danych wykorzystuje się różnorodne techniki - jest wręcz pożądane, aby podchodzić do niego z możliwie najróżniejszych perspektyw w celu uzyskania większej pewności, że rzeczy faktycznie mają się tak, jak się nam wydaje" [Angrosino 2010]) - netnografia rozwija się zgodnie z pięcioma krokami badań etnograficznych oraz podobnie, jak ona stanowi metodę naturalistyczną.

$\mathrm{Z}$ kolei analiza sieci społecznych jest metodą skupioną na wzorcach oraz strukturach relacji, które zachodzą wśród aktorów społecznych, którzy funkcjonują w ramach danej sieci (Berkowitz 1982; Wellman 1988).

„Analiza sieci społecznych stawia sobie za cel opisanie sieci relacji w możliwie najpełniejszy sposób, wydobycie podstawowych wzorców cechujących te sieć, prześledzenie przepływu informacji (oraz innych zasobów) w sieciach, a także dotarcie do tego, jaki wpływ wywierają te rację oraz sieci na ludzi i organizacje” (Garton, Hoythornthwaite i Wellman 1999: 75).

Ze względu na swoją wielopłaszczyznową działalność oraz szeroką obecność w cyberkulturze ruchy kobiece tworzą mocno zarysowaną społeczność w Internecie, której działania coraz częściej widoczne są na forach dyskusyjnych, czatach, portalach społecznościowych, stronach różnego typu stowarzyszeń, czy też blogach.

Badania na potrzeby artykułu były przeprowadzane przez okres około 100 godzin na wyżej wymienionych płaszczyznach online ze szczególnym uwzględnieniem portali społecznościowych. Badaczka śledziła fora internetowe, była obserwatorem chatów i dyskusji na nich, starała się odnotowywać szczególne interakcje między członkami.

Poza obszerną obserwacją całościowej przestrzeni grup, ruchów, portali społecznościowych i forów autorka badań zdecydowała się również na pogłębione zbadanie 100 najświeższych, czyli najbardziej aktualnych postów w każdej z wyżej wymienianych grup oraz 1000 komentarzy dotyczących aktualnie publikowanych postów. Celem badania było przybliżenie idei danych grup oraz skonfrontowanie głównych celów grupy zawartych w regulaminie $\mathrm{z}$ faktycznymi działaniami mającymi miejsce $\mathrm{w}$ wirtualnym świcie po przez narzędzie, jakim jest słowo.

Należy wspomnieć, iż badania pokryły się z ważnym, wywołującym negatywne odczucia, niemniej istotnym społecznie wydarzeniem a mianowicie śmiercią prezydenta miasta Gdańsk, co zdecydowanie wpłynęło zarówno na treść publikowanych postów, jak i komentarze pod nimi, a tym samym mogło mieć wpływ na wyniki przeprowadzonych badań. 
W związku z tym, iż badane środowisko, badana społeczność jest grupą zamkniętą, przynależność do niej na potrzeby badań była mocno ograniczona. Wpłynęło to na ograniczenia, jakie pojawiły się $\mathrm{w}$ trakcie przeprowadzania samych badań. Ze względu na weryfikację członków grup, na których aktywną działalność prowadzą ruchy kobiece badaczka przed przyjęciem do większości forów, grup była zobligowana do wypełnienia kwestionariusza. Pytanie kwestionariuszowe najczęściej poruszały zagadnienia działalności feministycznej, powodów, dla których chce się przynależeć do grupy oraz zdania na temat obecnej politycznej sytuacji kobiet. W związku z prawdopodobnie niezadowalającymi administratora grupy udzielonymi odpowiedziami badaczka nie uzyskała możliwości dołączenia do dwóch grup na portalu społecznościowym Facebook, co spowodowała zawężenia grupy badawczej.

Ponadto, jako nowy członek grup i forów feministycznych badaczka miała ograniczony wgląd tylko do wybranych publikowanych treści, z kolei w jednej z grup nie mogła komentować pojawiających się treści.

\section{BADANIA ETNOGRAFICZNE: IDEE FEMINISTYCZNE W DYSKURSIE ORGANI- ZACJI KOBIECYCH W SIECI}

Autorka w swoich badaniach skupiła się na najbardziej aktywnych kanałach przekazu online badanej społeczności - forach dyskusyjnych, portalach społecznościowych oraz stronach internetowych stowarzyszeń.

Obecnie w Ośrodku Informacji Kobiecej (tak zwanej OŚCE) jest zarejestrowanych 350 stowarzyszeń, grup nieformalnych oraz organizacji reprezentujących ruch kobiecy. Jednak w środowisku internetowym jest tylko kilka najbardziej widocznych grup oraz stworzonych przez nie inicjatyw i happeningów. Wymieniono te, które z uwagi na częstotliwość i zasięg swojego działania w sieci uznano za czołową reprezentację ruchów kobiecych w wirtualnej rzeczywistości społecznej.

\section{STRAJK KOBIET}

Niezależny ruch, bezpartyjna inicjatywa kobiet protestujących oraz działających głownie na rzecz praw kobiet, demokracji oraz szerokorozumianego równouprawnienia. Mobilizuje kobiety, choć nie tylko do walki już w ponad 150 miastach. Znakiem rozpoznawczym jest głowa kobiety z czerwoną błyskawicą na czarnym tle, który krążąc po internetowej przestrzeni, a później również w realnym środowisku stał się symbolem strajkujących kobiet w całej Polsce.

Ruch, który stał się inicjatorem oraz organizatorem ogólnopolskiego strajku kobiet 3 października 2016 roku. Październikowy strajk zapoczątkował solidarność kobiet z innych państw z walczącymi Polkami. Solidarność kobiet między innymi z Korei, Ameryki Łacińskiej czy Rosji zaowocowała koalicją kobiet w ponad 60 państwach. Ruch Strajk Kobiet poza strajkiem październikowym był również organizatorem takich akcji, jak: Czarny Poniedziałek, Czarny Piątek, Międzynarodowy Strajk Kobiet 8 marca, \#SłowoNaNiedzielę - Wieszak dla Biskupa, czy \#DziewczynyDoWyborów.

Strajk Kobiet to ruch, który nie posiada zarządu ani siedziby. Miejscem wspólnych „spotkań” jest Internet - forum dyskusyjne, fanpage na portalu społecznościowym 
oraz strona główna ruchu. O sprawy organizacyjne, finansowe czy prawne dba tzw. „helpdesk”, czyli ogólnopolski komitet wsparcia.

Działalność ruchu w świecie online kontroluje i wspiera grupa administratorów, którzy przez większość czasu starają się dbać o przepływ informacji, interakcje członków ruchu, a przede wszystkim o bezpieczeństwo członków w wirtualnym świecie.

\section{DZIEWUCHY DZIEWUCHOM}

Jedna z największych (ponad 100 tysięcy członków) i najgłośniejszych grup reprezentujących ruch kobiecy skupiających społeczność jednego z potarli społecznych - Facebooka - w walce z zaostrzeniem Ustawy Antyaborcyjnej, grupa Pro Choice walcząca o wolność wyboru i szacunek dla kobiet.

Dziewuchy Dziewuchom to społeczność Facebooka skupiająca się wokół grupy dyskusyjnej (grupa zamknięta, do której przyłączyć mogą się wybrane osoby po udzieleniu odpowiedzi na zadane prze administratorów pytania) oraz ogólnodostępnej strony Facebooka.

Zarówno jedno, jak i drugie miejsce jest dedykowane wzajemnym aktom wsparcia, współpracy oraz dyskusji na temat bieżących wydarzeń dotyczących praw i wolności kobiet, nie tylko w Polsce, ale i na całym świecie.

\section{DZIEWUCHY POLSKIE}

Jedna ze społeczności internetowych, która powstała jako odłam grupy „Dziewuchy Dziewuchom”. Grupa, która liczy ponad 9,5 tysiąca członków - zarówno płci męskiej, jak i żeńskiej. Jak określają sami administratorzy jest to przestrzeń w otchłaniach Internetu, która ma być ostoją wsparcia, „miejscem transparentnej i demokratycznej dyskusji i samoorganizacji promującą feminizm, edukację seksualną opartą na wiedzy naukowej i wolność wyboru" (Dziewuchy Polskie). Jest to grupa, której nadrzędnym hasłem jest „Pamiętajmy: solidarność naszą bronią!” (Dziewuchy Polskie). Sam administrator grupy określa ją jako grupę wsparcia.

\section{\#CZARNYPIĄTEK \#CZARNYPROTEST}

Obecnie jedne z najbardziej rozpoznawalnych znaczników internetowych symbolizujących walkę ruchów kobiecych. Są to ogólnie rozpoznawalne znaczniki używane najczęściej na portalu społecznościowym „Instagram”, które używane są w celu zrzeszenia oraz zmotywowania do działania społeczność portalu w celu walki o prawa kobiet, prawo do równości, prawo do aborcji, prawo do wolnego wyboru. Obecnie (stan na 06.01.2019) znacznik \#czarnyprotest znajduję się w 89,1 tysiąca postów, z kolei \#czarnypiątek to około 12,8 tysiąca postów.

Do akcji organizowanej na wcześniej wspomnianym portalu społecznościowym opatrzonej znacznikami \#czarnyprostest i \#czarnypiątek przyłączyli się również polscy aktorzy, artyści i celebryci, a w ślad za nimi protest polskich kobiet wsparło również wiele zagranicznych gwiazd między innymi Chris Colls, Alexanda Agoston oraz Adwoa 
Aboah.

Dzięki ogólnoświatowemu zasięgowi portalu Instagram ludzie na całym świecie przyłączyli się do internetowej walki polskiego ruchu kobiecego.

\section{WALKA ONLINE - MOWA MIŁOŚCI CZY MOWA NIENAWIŚCI?}

Tematyka forów, na których udzielają się członkowie grup kobiecych kumuluje się głównie wokół tematów związanych z prawami kobiet oraz sytuacją kobiet na świecie. Poza funkcją informacyjną fora spełniają jeszcze jedną, ważną funkcje - wspierającą. Fora, grupy, blogi to miejsca w przestrzeni online, gdzie ludzie o podobnych pomysłach, priorytetach, zdaniach czy przekonaniach jednoczą się i współdziałają. Podobnie dzieje się w przypadku ruchów kobiecych, które to poza wzajemnym wsparciem mobilizują się do zbiorowej walki o „lepsze jutro dla kobiet”, do walki nie tylko internetowej, ale często do realnych działań w przestrzeni publicznej.

Warto zaznaczyć, iż członkami ruchów kobiecych, czy to w stowarzyszeniach, grupach, czy też ruchach nie są, jak mogłoby się wydać, wyłącznie kobiety. Często w toczących się w wirtualnym świecie dyskusjach można spotkać również głosy mężczyzn. Mężczyzny - ojca, brata, narzeczonego, męża, który jest obecny w ruchu kobiecym z potrzeby wsparcia, w związku ze zgodnością idei, z chęci pomocy i wspólnej walki, jednak nierzadko z ciekawości.

Ze względu na interakcje, dyskusje, wymiany informacji, a co z tym związane poglądów w cyberświecie, tak jak w świecie realnym istnieją kodeksy, prawa, regulaminy. Z założenia przestrzeń online ma być wolna od tak zwanego „hejtu”, czyli szeroko rozumianej mowy nienawiści, zwłaszcza w grupach, które z założenia walczą o „lepszy świat”.

W trakcie badań autorka spotkała się w większości badanych przestrzeni z konkretnym regulaminem określającym zasady panujące wśród członków, którego głównym punktem był zakaz szerzenia agresji i nienawiści.

Badania wykazały również, iż w większości badanych przestrzeni zaakceptowany przez członków grupy regulamin jest akceptowany, a przede wszystkim respektowany wyłącznie teoretycznie. Na forach, a zwłaszcza grupach na portalach społecznościowych można zauważyć szerzącą się niechęć do wszelkich przejawów tego, co jest sprzeczne z wyznawanymi przez członków grupy wartościami.

Warto zauważyć, iż nie jest to nienawiść wymierzona bezpośrednio w konkretną osobę, jednak nierzadko jest to agresywne słownictwo, często nigdzie niepotwierdzone negatywne informacje, które mają na celu podsycanie wrogości i negatywnych odczuć względem „przeciwnika” - przedstawicieli władz i np. wprowadzanych przez nich ustaw, mediów, czy też np. konkretnych przedstawicieli osób publicznych. Agresja i mowa nienawiści objawiają się również poprzez bardzo dosłowne, osobiste a wręcz wyolbrzymione traktowanie tego, co dzieje się na świecie, w mediach, a co z tym związane automatyczny atak, jako forma obrony.

W wielu wpisach dotyczących wymogu szacunku - najczęściej - do kobiet, przekornie, to właśnie kobiety w sposób wrogi i agresywny wyrażają się o innych osobach - nierzadko innych kobietach, instytucjach, czy zdarzeniach. 
Poniższa tabela (tabela 1.) przedstawia liczbowe zestawienie postów na każdej z badanych grup z wyszczególnieniem podziału postów na wspierające lub popierające, posty agresywne i atakujące oraz posty neutralne, często typowo informacyjne. W dwóch pierwszych z przedstawionych w tabeli porównawczej grup tj. Strajk Kobiet oraz Dziewuchy Dziewuchom największy odsetek stanowią posty neutralne/informacyjne (kolejno: 88\% i 68\%), z kolei w grupach Dziewuchy Polskie oraz w instagramowych postach oznaczonych \#czarnypiątek \# czarnyprostest największą rolę pełnią posty wspierające (68\% oraz $82 \%$ ). We wszystkich przedstawionych grupach najmniejszy odsetek stanowią posty agresywne lub atakujące (kolejno: 8\%, 3\%, 9\%, $6 \%)$.

\begin{tabular}{|c|c|c|c|c|}
\hline GRUPA & $\begin{array}{c}\text { Liczba zbada- } \\
\text { nych postów }\end{array}$ & $\begin{array}{c}\text { Liczba postów } \\
\text { wspierających/ } \\
\text { popierających } \\
\text { działania }\end{array}$ & $\begin{array}{c}\text { Liczba postów } \\
\text { agresywnych/ } \\
\text { atakujących }\end{array}$ & $\begin{array}{c}\text { Liczba postów } \\
\text { neutralnych/in- } \\
\text { formacyjnych }\end{array}$ \\
\hline $\begin{array}{c}\text { STRAJK KO- } \\
\text { BIET }\end{array}$ & 100 & 4 & 8 & 88 \\
\hline $\begin{array}{c}\text { DZIEWUCHY } \\
\text { DZIEWUCHOM }\end{array}$ & 100 & 28 & 3 & 23 \\
\hline $\begin{array}{c}\text { DZIEWUCHY } \\
\text { POSLKIE }\end{array}$ & 100 & 68 & 9 & 68 \\
\hline $\begin{array}{c}\text { INSTRAGRAM } \\
\text { \#czarnypiatek } \\
\text { \#czarnyprotest }\end{array}$ & 100 & 82 & 12 & \\
\hline
\end{tabular}

Tabela 1. Podział badanych postów ze względu na charakter zwartego w nim przekazu Źródło: opracowanie własne

Tabela 2. prezentuje z kolei wyniki badań, których celem było przedstawienie intencji członków grup wyrażanych w komentarzach pod opublikowanym postem. W przypadku tego badania wyniki są zdecydowanie bardziej różnorodne, jednak przedstawiają też dużo wyraźniej niepokojące zjawisko - szerzące się wrogie interakcje członków grup w stosunku do siebie samych, jak i osób „z poza”.

Badania wykazują, iż przeważającą (od 40\% do niemalże 70\%) część komentarzy stanowią komentarze wspierające i popierające np. działania organizatorów grupy, niewielka część (średnio około 20\%-25\%) to komentarze neutralne, często czysto informacyjne pozbawione zabarwienia emocjonalnego.

Pozostałe komentarze to wiadomość pełne wrogiej postawy, nienawiści, czasem wręcz gróźb. Najmniejsza liczba komentarzy wrogich występowała na Instagramie pod 
postami oznaczonymi jako \#czarnypiątek oraz \#czarnyprotest i stanowiła ona 17,4\% wszystkich zbadanych komentarzy na tej przestrzeni. Natomiast największy odsetek negatywnych komentarzy widoczny jest w grupie Strajk Kobiet i wyniósł 46\%.

\begin{tabular}{|c|c|c|c|c|}
\hline GRUPA & $\begin{array}{c}\text { Liczba } \\
\text { zbadanych } \\
\text { komentarzy }\end{array}$ & $\begin{array}{c}\text { Liczba ko- } \\
\text { mentarzy wspie- } \\
\text { rających/ } \\
\text { popierających } \\
\text { działania }\end{array}$ & $\begin{array}{c}\text { Liczba ko- } \\
\text { mentarzy agre- } \\
\text { sywnych/ } \\
\text { atakujących }\end{array}$ & $\begin{array}{c}\text { Liczba ko- } \\
\text { mentarzy neu- } \\
\text { tralnych/infor- } \\
\text { macyjnych }\end{array}$ \\
\hline $\begin{array}{c}\text { STRAJK KO- } \\
\text { BIET }\end{array}$ & 1000 & 370 & 460 & 170 \\
\hline $\begin{array}{c}\text { DZIEWUCHY } \\
\text { DZIEWUCHOM }\end{array}$ & 1000 & 600 & 120 & 280 \\
\hline $\begin{array}{c}\text { DZIEWUCHY } \\
\text { POSLKIE }\end{array}$ & 1000 & 400 & 320 & 280 \\
\hline $\begin{array}{c}\text { INSTRAGRAM } \\
\text { \#czarnypiatek } \\
\text { \#czarnyprotest }\end{array}$ & 1000 & 686 & 174 & 140 \\
\hline
\end{tabular}

Tabela 2. Podział komentarzy ze względu na charakter zwartego w nim przekazu Źródło: opracowanie własne

W przedstawionych wynikach badań zauważalna jest wysoka dysproporcja postów wspierających i negatywnych do komentarzy użytkowników o tym samym nacechowaniu emocjonalnym. Istotną konkluzją wynikająca z badań autorki jest to, iż wrogie interakcje coraz częściej pojawiające się w wirtualnej przestrzeni są działaniami, a co z tym związane intencjami nie tyle założycielek/założycieli grup, ruchów, blogów, a często reakcją obserwatorów i członków danej internetowej społeczności.

W wielu przypadkach widoczna jest konkretna, niemniej kulturalna reakcja ze strony administratorów upominająca do zachowaniu kultury i nieszerzenia wrogich, gniewnych postaw wśród innych członków grupy.

Przykłady komentarzy reprezentujące wrogie interakcje (pisownia oryginalna):

„Gdybym miał do wyboru szatana i pedofila wybrałbym szatana. Pedofil kościelny jest gorszy szatana. Pedofil wykorzystuje ufność dziecięcą-to jest straszne! (Strajk Kobiet)

„To robota w dużej mierze kościoła katolickiego głównego mąciciela i hamulca rozwojowego, kobiety opuśćcie kościół!!!” (Strajk Kobiet)

„Kościół i przestępcy konstytucyjni z PiS muszą być ukarani.” (Instagram)

„A co ma przepaść do drących się dzieciaków w miejscu, które ma być relaksujące dla dorosłych? Jakby mi jakieś darło ryja u kosmetyczki to bym w taką przepaść skoczyła." (Dziewuchy Polskie) 
„Trzymaj wacka w rozporku ty stary zboku a nie agituj do popełnienia mordu na niewinnych.” (Instagram)

„To jest kurwa skandal !!! (Dziewuchy Polskie)

„Co za pojeby ... Nie wiem co biorą, ale ja po ich pomysłach muszę zacząć brać alprazolam.” (Dziewuchy Polskie)

„To zróbcie sobie jak was dupa boli.” (Dziewuchy Polskie)

Przykłady komentarzy wspierających/ motywujących (pisownia oryginalna):

„Jest mi ogromnie przykro. Potrafię współczuć, jak bardzo jest być fair względem siebie i swojej moralności a miłości do dziecka (choć nie mam własnego). Jesteście kochane, mądre i cudowne. Nie możecie brać winy drugiej osoby na swoje barki. Podziwiam za postawę.” (Dziewuchy Polskie)

„Brawo dla młodych ludzi. Popieram was.” (Dziewuchy Polskie)

„Jurku kochamy Cie <3” (Dziewuchy Dziewuchom)

„\#MuremZaJurkiem” (Instagram)

„Wielkie gratulacje, wierzyłam w milion” (Dziewuchy Dziewuchom)

„Super, ze wymyśliłyście grafikę, naprawdę za to dziękuję <3.” (Dziewuchy Dziewuchom)

„Super, popieram <3” (Instagram)

„Brawo kobiety!” (Instagram)

„Jestem z wami! <3” (Instagram)

„\#girlspower!” (Instagram)

\section{PODSUMOWANIE}

Ruchykobiecetotemat,któryswójpoczątekmiałw1972 roku,niemniejjesttotematwciąż aktualny. Kobiety XXI wieku niezależnie od kontekstu kulturowego starają się walczyć o równość,oprawa (por.Demiral 2019; Odrowąż-Coates 2019; Offiong 2019;Zsogon2019), o spokój, jak same często zauważają o „ludzkie traktowanie”. Walczą o lepsze jutro, jednak nie same kobiety i nie tylko dla kobiet. To działaniom ruchów kobiecych przypisuje się obecny „chaos”, który dzieje się na polskiej scenie politycznej. Ruchy kobiece to następczynie sufrażystek, które w swoich działaniach, jak same zaznaczają, skupiają się na szeroko rozumianym dobru kobiet oraz budowaniu lepszej, równej przyszłości dla wszystkich.

W obliczu ówczesnych wydarzeń mających na celu wprowadzenie wielopłaszczyznowych ograniczeń dotykających kobiet, to właśnie one chcą walczyć - nie tylko w 
wirtualnym świecie. Mimo trudności z jakimi spotkała się autorka badań podczas ich przeprowadzania, m.in. ograniczony dostęp do badanych grup oraz możliwość obserwacji tylko wybranych przez administratora grupy postów oraz komentarzy, jej badania wskazują, iż „kobiety walczące” mają granice wytrzymałości, a walka , jak same określają, „o siebie”, o wolność słowa i działania, o równość spowodowała, że coraz częściej na forach, portalach społecznościowych reprezentujących ruchy kobiece, blogach, grupach poza znaczącą ilością motywacji, wsparcia i mobilizacji do wspólnej walki coraz częściej można spotkać przejawy wrogich emocji, które w coraz większych ilościach wydobywają się z postów, czy komentarzy umieszczanych we wspólnej przestrzeni online.

\section{BIBLIOGRAFIA}

Angrosino, Michael. 2010. Badania etnograficzne i obserwacyjne. Warszawa: Wydawnictwo Naukowe PWN, s: 19.

Berkowitz, Steve D. 1982. An Introduction to Structural Analysis. The Network Approach to Social Research, Toronto: Butterworth.

Demiral, Seran. 2019. There is no discrimination between girls and boys! "Society Register” 3(4): 137-156. https://doi.org/10.14746/sr.2019.3.4.08

Garton Laura, Haythornthwaite Caroline, Wellman Barry. 1999. Studying On-line Social Network. W: Stave Jones (red.), Doing Internet Research. Critical Issues in Methods for Examining the Net, Thousand Oaks, CA: Sage, s. 75.

Humm, Maggie. 1993. Słownik teorii feminizmu, Tłum: B. Umińska, J. Mikos. Warszawa: Wydawnictwo Naukowe Semper.

Kozinet, Robert V. 2012. Netnografia. Badania etnograficzne online. Warszawa: Wydawnictwo Naukowe PWN, s. 13, 93, 100.

Lewandowska, Ewa. 2003. Feminizm a globalizacja. „Dziś” nr 12.

Odrowąż-Coates, Anna. 2014. Gender crisis in Poland, Catholic ideology and the media. “Sociology Mind” 5(01): 27-34. http://dx.doi.org/10.4236/sm.2015.51004

Odrowąż-Coates, Anna. 2015. Is gender neutrality a post-human phenomenon? The concept of 'gender neutral' in Swedish education. "Journal of Gender and Power" 3(1): $113-133$.

Odrowąż-Coates, Anna. 2019. Gender equality and children's equality in liberal and conservative discourses: Implications toward language and society. "Society Register” 3(4): 7-16. https://doi.org/10.14746/sr.2019.3.4.01

Offiong, Ekwutosi E. 2019. Language and discourse in Nigerian Education: Historic implication of gender issues. "Society Register" 3(4): 37-56. https://doi.org/10.14746/ $\underline{\text { sr.2019.3.4.03 }}$

Tokarczyk, Roman. 2005. Wspólczne doktryny polityczne. Kraków: Oficyna a Wolters Kluwer Business.

Wajbert-Wąsiewicz, Ewelina I. 2017. Feminizm w polskiej literaturze kobiet. "Annales Universitatis Mariae Curie-Skłodowska” Vol. XV, 2. 
Wollman, Barry. 1988. Structural Analysis. From Method and Metaphor to Theory and Substance. W: Barry Wellman, Stephan D. Berkowitz (red.) Social Structures. A Network Approach, Cambridge, UK: Cambridge University Press, s. 19-61.

Wollstonecraft, Mary. 2011. Wolanie o prawa kobiet. Warszawa: Mamania.

Zsogon, Maria C. 2019. Girls' exploitation in the Triple Border among Argentina, Brazil and Paraguay: between colonialism and human rights narratives. "Society Register" 3(4): 57-74. https://doi.org/10.14746/sr.2019.3.4.04

\section{NETOGRAFIA}

Dziewuchy Dziewuchom- grupa na portalu Facebook, https://www.facebook.com/ groups/114342355632125/ [Dostęp: 12.12.2018].

Dziewuchy Dziewuchom- Organizacja Społeczna, https://www.facebook.com/dziewuchydziewuchom/?ref=br_rs [Dostęp: 13.12.2018].

Dziewuchy Polskie, https://www.facebook.com/groups/1562628830530524/ [Dostęp: 12.12.2018].

Instagram https://www.instagram.com/ [Dostęp: 10.12.2018].

Strajk Kobiet - Facebook, https://www.facebook.com/ogolnopolskistrajkkobiet/?fref=ts [Dostęp: 19.12.2018].

Strajk Kobiet - Instagram, https://www.instagram.com/strajk_kobiet/ [Dostęp: 20.12.2018].

Strajk Kobiet, http://strajkkobiet.eu/ [Dostęp: 18.12.2018].

\section{The activity of women's movements on the Internet - the digital face of Polish feminism}

ABSTRACT: The author of the text touches upon the subject of the virtual activity of women's movements in Poland. By using the netography method, with the specific application of an analysis of social networks, she looks at the digital image of Polish feminism, paying attention to the positive and negative aspects accompanying women in their struggle in online space. The author's main goal was to study the language used by contemporary feminists in the virtual world, whether it is a language of love or a language of hate.

The article presents the activities of women's organizations online, making an attempt at outlining the main ideas visible in the discourse of these movements. Owing to the conducted analysis, the author presents the impact and the clearly outlining intentions of women's movements online, with particular attention paid to both the positive and the hostile interactions in the feminist online space.

KEYWORDS: women's movements, Internet, feminism, Cyberspace, netnography, social network analysis 
